\title{
Полянський B.A.,
}

професор кафедри інструментально-виконавської майстерності

Iнституту мистеитв

Київського університету імені Бориса Грінченка,

заслужений діяч мистецтв України

\section{Джазовий піанізм у контексті стильових тенденцій фортепіанного виконавства XX ст.}

У статті розглянуто процес становлення та стильову специфіку джазового піанізму у виконавському мистецтві XX cm. Розкрито передумови появи сучасного джазового фортепіано, що пов'язано зі зміною стилістичних епох, на прикладах творчості видатних представників джазового піанізму. Особливу увагу приділено характеристиці індивідуального стилю і творчої манери знакових музикантів минулого століття і сучасного покоління джазових виконавців.

Ключові слова: джаз, фортепіано, джазовий піанізм, імпровізачія, традичії, стиль.

\section{Полянский B.A.}

Джазовый пианизм в контексте стилевых тенденций фортепианного исполнительства XX B. В статье рассмотрена история становления и стилевая специфика джазового пианизма в исполнительском искусстве XX в. Раскрыты предпосылки появления современного джазового фортепиано, что связано со сменой стилистическихэпох, на примерах творчества выдающихся представителей джазового пианизма. Особое внимание уделено характеристике индивидуального стиля и творческой манеры знаковых музыкантов прошлого века и современного поколения джазовых исполнителей.

Ключевые слова: джаз, фортепиано, пианисты, импровизация, традиции, стиль.

\section{Polyanskyi V.A.}

Jazz Pianism in Context of Piano Performance Style Tendencies of $20^{\text {th }}$ Century

The acticle is devoted to the development and style specifics of the jazz pianism in performing arts of the $20^{\text {th }}$ century. It is an attempt to consider historic pre-conditions for the contemporary piano jazz image, special attention is paid to the individual style characteristics and creative peculiarities of the most prominent musicians of the last century and contemporary young jazz performers.

Piano is an instrument with long history and rich traditions. Over the past three hundred years creating and performing piano music (first for the keyboard instruments) has been playing a vital and steadily growing role both in music creativity and in the development of music instrumentalism on the whole. Therefore, piano creativity and art have become the phenomenon to a certain degree comparable to music art in general. Piano jazz performing based on the musical instrument, which made up a great epoch in the European academic music, could not avoid influence on the vast heritage of the piano art. The emergence of piano in jazz allowed to discover new, truly endless horizons of the further development for piano performance. It is to be noted that the instrument with a three-century history has managed to harmoniously express the heart of jazz thinking, most efficiently show the merits of jazz music, and encourage the appearance of a powerful range of performers to make up a most valuable asset and pride for the jazz history. Like any live art, jazz is continuously developing, and, as history has shown, quite rapidly. Indeed, the huge distance between the music of New Orleans street orchestras of the early $20^{\text {th }}$ century and today's electronic innovations has been covered at a high speed. Over its 100-year history it has coped with the style evolution comparable to that of the European academic music, which took over four centuries. Archaic, traditional, swing, bebop, hard bop, cool jazz, modal jazz, third stream, and further on to the unrestricted free jazz improvisation - this is the diachronic outline of the sequence of jazz styles.

Key words: jazz, piano, piano players, improvisation, traditions, style.

$\Pi$ остановка проблеми. У системі сучасної музичної освіти України мистецтво джазу посідає особливе місце. Майже в усіх середніх та вищих музичних навчальних закладах діють відділення, де вивченню джазу, зокрема фортепіанному, приділяється значна увага.

Фортепіано - один 3 небагатьох інструментів, який, будучи тісно пов'язаний з класичною 
академічною традицією, займав і займає в джазі ключове положення. Надзвичайно активне і творче використання фортепіано не лише збагатило джазову музику, але й сформувало плеяду потужних виконавців, кожен 3 яких $є$ гордістю джазового мистецтва. Саме піаністи займають провідні позиції в історії еволюції джазових стилів: вони керували біг-бендами, складали i аранжували для них композиції, диригували оркестром «від фортепіано» подібно до того, як Й.С. Бах та Й. Гайдн диригували «від чембало» своєю оркестровою музикою. Архаїчний, класичний джаз, свінг, бібоп, кул, хард-боп, фрі-джаз, джаз-рок - так у історичній перспективі виглядає зміна яскравих індивідуальних джазових стилів, кожен з яких породив видатних представників у світі джазового піанізму.

Але висвітлення історичних та теоретичних аспектів фортепіанного джазового виконавства, на нашу думку, недостатньо обгрунтовує урахування саме фортепіанної специфіки. Таким чином, проблема грунтовного вивчення стилістичних аспектів джазового піанізму в історичній перспективі $є$ актуальною, оскільки без цього неможливе професійне розуміння культури джазу.

Аналіз останніх досліджень і публікацій. Звертаючись до вивчення тенденцій розвитку фортепіанного джазу, доводиться визнати, що вітчизняних публікацій із зазначеної тематики вкрай мало. Переважна кількість джерел це дослідження іноземних авторів, не перекладені українською, що суттєво ускладнює роботу з ними. 3-поміж українських видань відзначимо насамперед «Основи джазової інтерпретації» I. Горвата й I. Вассербергера в перекладі зі словацької мови та посібники для гітари В. Молоткова i В. Манілова («Музична Україна», 1980). 2004 р. у видавництві «Мелосвіт» вийшла друком збірка «Негритянські блюзи» В. Полянського, а 2012 - книга цього ж автора російською мовою «Королі джазу», у якій представлено сім біографій піонерів джазового рояля. Нарешті, у 2014 р. вийшло друком фундаментальне дослідження В. Полянського в співавторстві з Т. Полянським «Доба регтайму». Цими виданнями фактично вичерпуються вітчизняні бібліографічні джерела щодо проблематики фортепіанного джазу.

Теоретичним підгрунтям даної статті $€$ насамперед дисертаційні дослідження А. Лозовського, В. Олендарьова та В. Романка, роботи зарубіжних музикознавців С. Беліченко, Д. Берендта, Б. Гнілова, С. Ісакоффа та Д. Коллієра, у яких, хоча і фрагментарно, але грунтовно висвітлено важливі аспекти означеної проблеми. Для відтворення інформаційного поля проблеми стали у пригоді поодинокі публікації в періодичних музичних виданнях та на інтернет-ресурсах, присвячені певним подіям, музичним програмам, персоналіям тощо.
Мета статті - окреслити шляхи становлення джазового піанізму в історичній перспективі стильового розвитку джазу XX ст. на прикладах творчості відомих музикантів. Означена мета передбачає розв'язання таких завдань: розглянути історичні етапи розвитку фортепіанного джазу; надати характеристику провідним стильовим течіям і тенденціям розвитку джазового мистецтва; визначити взаємозв'язок специфіки сучасного джазового піанізму та джазового фортепіано.

Виклад основного матеріалу. Музичне мистецтво зазвичай стає знаком тієї історичної доби, до якої належить. Для бурхливого і суперечливого XX ст. таким документом часу став джаз, який набув безпрецедентного поширення у всьому світі і багато в чому змінив художній образ сучасності. Сьогодні джаз позиціонує себе як «транснаціональний фольклор», всепланетарне мистецтво, носій загальнолюдського начала, звернений до інтернаціональних проблем, як «нова усна культура», покликана потіснити письмову культуру, блоковану інформаційним бумом [7, 141].

Сформований на грунті синтезу європейської та неєвропейської традицій, джаз безмежно розширив спектр музичних виражальних засобів і можливостей інструментів, виконавства в цілому, та, на думку німецького музикознавця I.Е. Берендта, «більше, ніж будь-який інший вид музики, став універсальною музично-художньою мовою в сучасному світі» $[9,332]$. До того ж, з'явившись як переважно розважальне мистецтво, джаз потужно вплинув на різні галузі художньої культури: літературу, театр, образотворче мистецтво, кіно, зачепив практично всі основні музичні жанри, часом дуже далекі від власне джазу як такого, у тому числі академічну музику. Характерним $€$ те, що джаз не став лише модною новинкою, а, витримавши випробування часом i натиск конкуруючих видів та жанрів музики, утвердився як мистецтво, варте серйозного аналітичного підходу, цілком усвідомлене в сучасному музикознавстві, що накопичило достатню кількість важливих робіт різного спрямування - від популярних джерел до фундаментальних досліджень.

Фортепіано - інструмент 3 тривалою історією та багатими традиціями в академічній музиці, який ось уже три століття перебуває в самому центрі музичного світу, відіграючи постійно зростаючу роль у композиторській творчості та в розвитку музичного інструменталізму. Величезний внесок у становлення фортепіано зробили провідні композитори XVIIIXIX ст., насамперед В.А. Моцарт і Л.В. Бетховен, творчість яких значною мірою мотивувала появу безлічі конструктивних змін інструмента. 3 початком доби музичного романтизму два 
видатних піаністи - Фредерік Шопен і Ференц Ліст - відкрили перед сучасниками нові, нечувані до того можливості інструмента. Геніальні творці, вони підготували грунт для появи таких гігантів, як Феруччо Бузоні, Антон Рубінштейн, в особі яких європейське фортепіанне виконавство досягло кульмінації і, як вважає більшість, навіть певної завершеності свого розвитку.

Однак саме в цей час за океаном у галасливих нічних шинках і салунах північного Нового Світу звучала музика, яка відкривала фортепіано з іншого, зовсім несподіваного боку, при цьому вочевидь ламаючи звичне уявлення про традиційну європейську піаністичну школу. Передусім в ній не було пієтету перед звуковою красою, витонченістю інтонування, вишуканістю фразування та іншими специфічними фортепіанними засобами - невід’ємними компонентами музичної культури Європи. Обдаровані чорношкірі піаністи-самоучки хвацько вибивали 3 клавіш бадьорі мелодії, у яких звична ритмічна рівновага була порушена посиленим синкопуванням, підкресленою ударністю, розстановками акцентів там, де за усталеними нормами їх не мало бути, прийомами, що сягають корінням афроамериканського фольклору. Цією музикою був регтайм - специфічний фортепіанний стиль, дивовижний синтез «білого» 3 «чорним», стихійного 3 раціональним, перший і найважливіший протожанр американського джазу, що став символом доби.

Походження регтайму історики тлумачать неоднозначно, але можна стверджувати напевно, що «хребтом» цієї музики була незвичайна ритміка - гостро синкопована і збуджена. Як зазначає В. Конен, «регтайм уражав уяву не лише поліритмічною структурою, а й тим, що саме ритм став провідним елементом виразності. Уперше в музиці Заходу постренесансної доби не мелодичне, a ритмічне начало стало головним об’єктом композиторської думки. Мелодія втрачала властиву їй у європейській музиці останніх трьох століть плавність, завершеність, мотивну інтонаційну насиченість» $[5,100]$.

Наприкінці XIX ст. фортепіано вже були всюди. За відсутності грамзаписів танцювальної музики, яка з'явиться пізніше, цей інструмент головував у клубах, барах, ресторанах та інших розважальних закладах, що стали в ті роки осередком музичного життя американців, незалежно від рівня достатку та кольору шкіри. Робота піаністів у подібних закладах відіграла величезну роль у становленні фортепіанного джазу. Насамперед вона відкривала широке поле для імпровізацій, пошуків і оновлень, сприяла появі нових виконавських тенденцій. Ініціаторами подібних процесів були талановиті негритянські самоучки, самородки, носії традицій тієї усної музичної культури, яка і лягла в основу джазу. Саме ці музиканти стали піонерами нових шляхів, справили істотний вплив на формування фортепіанного джазового виконавства. Створені ними стилі - Гарлем страйдпіано, барел-хауз-піано і хонкі-тонкі-піано, стомп-піано, фортепіанний стиль труби і стиль «зв'язаних рук» - підмурок, на якому грунтується весь джазовий піанізм.

На початку XX ст. з'явилася плеяда чудових піаністів, справжніх майстрів цих стилів. Серед них були безперечні лідери, які випереджали інших, найбільш повно виражали ті чи інші новації, музиканти, чий творчий геній окреслив шляхи джазового піанізму на десятки років уперед. Джеллі «Рол» Мортон, Джеймс П. Джонсон, Фетс Уоллер, Віллі «Лайон» Сміт, Ерл Хайнс, Арт Тейтум - ці імена золотими літерами вписані у почесний пантеон слави джазу. У цей же час заявила про себе група блискучих виконавців ще одного, не менш оригінального стилю-буги-вуги. Джиммі Янсі та Мід Лак Льюїс, Альберт Аммонс i Піт Джонсон, Біг Джо Тернер і «Пайн Топ» Сміт - музиканти, які зробили буги-вуги, мабуть, найбільш запальним і поширеним стилем фортепіанного джазу. Крім того, їхні знахідки лягли в основу виконавської манери піаністів майбутньої доби рок-н-ролу 1950-х років і ритм-ендблюзу наступних десятиліть.

До 30-х років ХХ ст. епоха класичного джазу добігала кінця. Починалася доба свінгу - час історичної зміни стилів і загального панування великих оркестрів, коли на перше місце вийшла колективна гра 3 пріоритетом індивідуальності тембру загального звучання в цілому, так званого оркестрового саунду. Сольне фортепіанне виконавство почало відходити на другий план, поступившись місцем новій манері піаністів, яка в руслі оркестрового джазу мала чітко узгоджуватися з вимогами партитури тієї чи іншої п’єси. Досить згадати «діалоги» оркестру та пружнонасичених вставок Дюка Еллінгтона, витончені акорди-краплі Каунта Бейсі, вишукані гнучкі соло Тедді Уїлсона в оркестрі Бенні Гудмена, різноманіття виконавських прийомів Бенні Пейна з оркестру Кеба Келлоуея, Джо Бушкіна з оркестру Томмі Дорсі та багатьох інших $[6,14]$.

При цьому фортепіанні стилі, попередники свінгу, не зникли, а продовжували співіснувати, взаємодіяти, підживлюючись новими підходами. Оновлений регтайм і страйд, буги-вуги і Гарлем - піано стиль, ансамблева гра в диксилендових складах і партії, написані аранжувальниками великих оркестрів, - усе це залишалося в арсеналі піаністів цього періоду.

Знаковою у творчості джазових піаністів стала поява нового ансамблевого складу - фортепіанного тріо. Цей інструментальний жанр добре відомий в академічній музиці, де його класичний тип склався ще в середині XVIII ст. 
Але якщо в академічній музиці це скрипка, віолончель і фортепіано, то у джазі традиційно - рояль, контрабас і ударні, хоча часто зустрічаються тріо, де замість барабанів - гітара. Гра без ударних інструментів робила звучання більш прозорим, давала змогу роялю з гітарою дублювати мелодію, грати унісонні рифові ходи, по черзі акомпанувати один одному, створюючи при цьому найвищу свінгову напругу. Один з яскравих прикладів - блискуче тріо Оскара Пітерсона (фортепіано) з Нільсом Педерсеном (контрабас) і Джо Пасом (гітара). Наразі не визначено, коли піаністи почали грати тріо, проте відомо, що Джеймс П. Джонсон грав у такому складі й навіть записувався в 1921-1929 рр., щоправда, не з контрабасом, а з корнетистом Джонні Данном, барабанщиками Едді Догерті чи Дані Алвином $[1,122]$.

Гра у класичному джазовому тріо (з контрабасом і барабанами) істотно змінила підходи до фортепіанного виконавства. Передусім вона звільнила ліву руку від крокуючої функції басакорд чи постійного гармонічного акомпанементу, що їх чудово міг виконувати контрабасист або той самий гітарист. Окрім цього піаніст тріо змушений був позбутися численних тремоло, широких акордів у правій руці, типової манери стилю страйд, а також відмовитися від безперервного соло, чутливо взаємодіючи 3 партнерами. Багато піонерів джазового фортепіано, такі як Нет Коул, Арт Тейтум, Фетс Уоллер, Ерл Хайнс, працювало у тріо. Цей оригінальний склад відкрив дорогу видатним музикантам наступного покоління: Джорджу Ширингу білому сліпому музикантові, автору багатьох «вічнозелених стандартів», один з яких ("Lullaby Of Birdland") поряд iз "Take the a Tran" Дюка Еллінгтона став воістину гімном джазу, а також улюбленцю мільйонів Ероллу Гарнеру та мультифункціональному генію Оскару Пітерсону, стиль якого вважався кращим зразком як у свінгу, так і в боni [6].

Важливий внесок у галузь фортепіанного джазу зробили піаністи, творчість яких змусила говорити про новий напрям у джазовому фортепіанному виконавстві. Ахмад Джамал - витончений мінімаліст, «майстер музичної економії», як назвали його критики; Джон Льюїс - творець знаменитого «Модерн Джаз Квартету» (МДК), музика якого максимально інтегрована у класичні зразки, щонайбільше наближена до стандартів західноєвропейського музикування; Дейв Брубек із його гармонічними складнощами, політональністю, поліфонією, застосуванням непарних розмірів і відходом від стандартних «варіацій на тему»; Ленні Тристано - експериментатор, переконаний апологет інтуїтивного джазу, нової імпровізаційної (чи вільної) музики, який остаточно порвав із класичним напрямком, а також інші музиканти-новатори.
У середині 40-х років джаз поступово втрачає свою розважальну функцію, дедалі більше схиляючись до серйозності, можна сказати, елітарності. Кардинальні зміни, що відбулися в інструментальній виконавській стилістиці, призвели до появи модерн-джазу - музики, різко відокремленої від усього попереднього розвитку, більше орієнтованої на слухання, ніж на танці (до речі, поняття модерн-джаз залишається незмінним донині). Ця музика, народжена в результаті грандіозного експерименту молодих виконавців, які прагли боротьби, хотіли грати по-новому, говорити іншою музичною мовою, отримала назву бi-боn. Зараз неможливо, та й, мабуть, безглуздо говорити про походження цього терміна. Самі музиканти пояснюють це банальним звуконаслідуванням, подібно до його вокальних варіантів (cкеm). Так ця абстрактна фраза набула функції такої собі джазової етикетки, і цілком вірогідно, що могло бути і будь-яке інше слово чи словосполучення. Приміром, у 1944 р. Діззі Гіллеспі одну зі своїх композицій так і назвав — «Бі-боп», a Лайонел Хемптон, вібрафоніст доби свінгу та подальших джазових стилів, нерідко під час гри хвацько підспівував приблизно наступне: «Хей-ба-ба-риба-боп, ба-бу-ба-бу-бібоп».

Звуки нового джазу вразили публіку своєю несподіваністю, здавалися зухвалими, занадто настирними, і природно, що спочатку далеко не всі оптимістично зустріли появу цієї малозрозумілої музики. Навіть «зірки джазу» вважали їі просто абсурдною і нелегко долали бар'єр неприйняття починань молодих музикантів. Так, Луїс Армстронг, почувши їхні імпровізації, сказав, що «не розуміє, що роблять ці хлопці». I таке ставлення можна пояснити: музична мова боперів різко відрізнялась від стилів, що панували до середини 40-х років, передусім від традиційного джазу. Свої імпровізації вони будували за абсолютно новими правилами, у шалених ритмах, на невідомих раніше хитромудрих гармонічних сітках, по-іншому розставляючи акценти. Їхні соло - бурхливі, віртуозні, 3 безперервними переходами мелодії від одного голосу до іншого, насичені новою ритмопластикою, являли собою радикальні відхилення від усього, що було до цього. Рухаючись у бік ускладнення, новий джаз навмисно відходив від властивої попередньому стилю свінг танцювальності, а це вимагало вже іншого способу існування, як і більш підготовленого слухача. Тож виконавці перемістилися у джаз-клуби, в аудиторії університетів і коледжів, у театри і концертні зали. Так джаз стає інтелектуальним мистецтвом, виходить на концертну естраду.

Піаністи приймають нововведення бi-бona. У цьому стилі, який передбачає здебільшого ансамблеву гру, піаніст, акомпануючи солісту, грає розрізненими акордовими вставками двома 
руками, а єдина пульсація повністю переходить до партії контрабаса. Фортепіанне соло зазвичай складається зі швидких імпровізаційних гамоподібних ліній у партії правої руки і коротких, синкопованих, дисонуючих акордів у лівій, «накладених» на безперервний пульс ритм-секції.

Одним із творців боny, поряд із такими титанами, як трубач Діззі Гіллеспі та саксофоніст Чарлі Паркер, був піаніст Телоніус Монк (Thelonious Monk) - геніальний реформатор, автор екстравагантних «вічнозелених тем», виконавець із оригінальною фортепіанною технікою, яка слугувала матеріалом для багатьох музикантів його доби та наступних поколінь.

Серед піаністів-боперів найзначнішою постаттю був Бад Пауел (“Bad” Powell) - блискучий і оригінальний артист джазу, чиї композиції, наповнені несподіваними гармоніями та мелодичними зворотами, донині включають у свій репертуар кращі сучасні джазмени. У числі найбільш яскравих представників, що визначили розвиток піанізму бопу та наступних стилів, слід відзначити такі імена, як Ел Хейг (Al Haig), Хенк Джонс (Hank Jones), Біллі Тейлор (Billy Taylor), Тед Дамерон (Tadd Dameron), а також Дюк Джордан (Duke Jordan), чия композиція “Jordu” стала класикою бi-бony, і нарешті, Білл Еванс (Bill Evans) - семиразовий лауреат премії «Греммі», навічно занесений до джазового пантеону слави, затверджений критиками найпрестижнішого джазового журналу «Даун Біт».

Реформи бопу заклали основу і дали потужний імпульс процесам, які кожне наступне десятиліття стимулюватимуть пошуки нових шляхів, розширюватимуть царину експериментів у галузі гармонії, метроритміки, композиції та форми. Чимало піаністів, які вийшли на сцену у другій половині ХХ ст., здобували академічну освіту (на відміну від власне боперів) i, маючи необхідний професіоналізм, почали практикувати взаємодію та синтез різних музично-мовних пластів: академічної традиції, елементів фольклору різних країн, прийомів, кліше популярної музики та багато іншого, що в підсумку стало головною тенденцією всього сучасного джазу.

Надалі опанування нової фортепіанної віртуозності призвело до появи універсальних виконавців, які виявляють інтерес до безлічі стильових моделей одночасно, органічно почувають себе в різних, часом радикально відмінних одна від одної течій і напрямів. Найбільш яскраві виконавці, що займають лідерські позиції та мають широкий арсенал технічних засобів, часто виступають у сольному форматі. У XXI ст. - це галузь, яка активно розвивається та є специфічною ознакою сучасного джазового піаніста.

Серед тих піаністів, початок кар'єри яких припадає на 1960-1970-ті рр., - Ч. Коріа, Х. Хенкок,
К. Джарретт, Б. Грін, М. Каміло, Г. Рубалькаба, Ч. Валдес, Д. Грузин, Д. Дюк, А. Фарао, Д. Семпл, К. Дрю, Д. Перез, Д. Террассон - музиканти високого творчого потенціалу, видатні виконавці сучасної джазової сцени. Без сумніву, найбільш значущі - це Чик Коріа і Хербі Хенкок. Саме вони упродовж десятиліть задають тон усьому фортепіанному джазу, визначаючи, по суті, вектор розвитку цього виду музичного мистецтва.

Поряд 3 іменитими майстрами потужно заявило про себе молоде покоління талановитих музикантів: Х. Уехара, Е. Джангіров, Б. Гочиашвілі, Т. Амасян, В. Айер, М. Робертс, А.Л. Нусса, Р. Гласпер і багато інших. Це активно концертуючі піаністи, що володіють бездоганною технікою, здатною викликати заздрість у класичного віртуоза, які прагнуть насамперед до звільнення джазового мистецтва від прикладних функцій та максимального зближення його 3 академічною музикою. Втілюючи свої ідеї у різноманітних проектах, вони охоче взаємодіють 3 представниками старшого покоління. Як приклад наведемо надзвичайно популярні виступи у форматі фортепіанного дуету: Ч. Коріа i Х. Уехара, Ч. Коріа і Ф. Гульда, Х. Хенкок і Ланг Ланг, Т. Амасян і М. Соляль.

Передові піаністи нової генерації - це музиканти, які зазвичай здобули грунтовну професійну підготовку, включаючи академічну. I це реалії нашого часу, оскільки сучасний джазовий піанізм неймовірно складний, побудований на високих вимогах нової віртуозної техніки, тому без солідної освітньої бази розраховувати на успішну виконавську кар'єру було 6 наївно, тим більш у професійному конкурентному середовищі.

Висновки. Джазовий піанізм сьогодні $є$ дуже різноманітним. Як і джаз у цілому, він продовжує активно поширюватися світом, охоплюючи все більше регіонів, країн, континентів. У XXI ст. це мистецтво найвищого професіоналізму, яке після приголомшливих новацій Сергія Прокоф'єва, Ігоря Стравінського, Бели Бартока, Антона Веберна, збагачуючись елементами інших музичних культур, продовжує розширювати й без того неосяжні кордони фортепіанного виконавства, зберігаючи при цьому основні традиції та здобутки попередників.

Сьогодні фортепіанний джаз опановують у провідних вищих та середніх мистецьких навчальних закладах, різних виконавських школах і спеціалізованих центрах. Молоді піаністи різних країн світу мають можливість слухати майстер-класи видатних виконавців і навіть грати з ними на численних фестивалях, які є однією із засадничих форм існування джазу. Усе це створює потужну музично-технічну базу та робить висококласну джазову освіту реальністю. 


\section{ДЖЕРЕЛА}

1. Беличенко С. Джаз для любознательных. Т. II / С.А. Беличенко. - Новосибирск : Сиб. унив. изд-во, 2012. - $260 \mathrm{c}$.

2. Гнилов Б.Г. Джазовый пианизм и фортепианное искусство / Б.Г. Гнилов. - М. : Московская государственная консерватория, 2003. - 192 с.

3. Зимин П. История фортепиано и его предшественников / П. Зимин. - М. : Музыка, 1968. - 214 с.

4. Исакофф С. Громкая история фортепиано. От Моцарта до современного джаза со всеми остановками / С. Исакофф. - М. : ООО «Издательство АСТ», 2013. - 480 с.

5. Конен В. Третий пласт / В. Конен. - М. : Музыка, 1994. - 160 с.

6. Корнев П.К. Джаз в культурном пространстве XX века : автореф. дис. ... канд. культурологии : 24.00.01 «Теория и история культуры» / П.К. Корнев. - СПб., 2009. - 22 с.

7. Корнев П.К. Искусство джаза / П.К. Корнев. - СПб. : Изд-во СПбГУКИ, 2009. - 240 с.

8. Мишин В. Магия африканской скульптуры и новый пластический язык [Электронный ресурс] / В. Мишин. - Режим доступа : http://www.picasso-pablo.ru/library/picasso-otrazheniyametamarfozy4.html

9. Berendt J.E. Photo-Story des Jazz. — Frankfurt a/M, 1978. 